\title{
Literacy learning problems: Developing the character of reading fondness in elementary school students during the COVID-19
}

\author{
Rahmat Aziz $\bowtie$ State Islamic University \\ Djoko Susanto, State Islamic University \\ Sabila Irwina Safitri, State Islamic University \\ Lina Izza Mazida, State Islamic University \\ Thomas Wijaya, State Islamic University \\ $\bowtie$ azira@uin-malang.ac.id
}

\begin{abstract}
Learning activities in developing the character of reading fondness in elementary school students during the COVID-19 period have raised difficulties for both teachers and students. Challenges that are not responded to appropriately and wisely by schools have resulted in low reading habits. This study describes the character of student reading fondness and analyses the teacher's role during the learning process. Data were obtained through an online questionnaire from 122 students and seven teachers in three elementary schools in Riau, Central Kalimantan, and East Java provinces. The data were analyzed using thematic analysis and reflective thinking. The results show that the teacher's difficulty in providing learning to students resulted in the quality of reading fondness in elementary school students. These findings reflect that COVID-19 has the effect of a social transformation in educational practice. This study suggests the use of different data collection methods to understand the case better.
\end{abstract}

Keywords: COVID-19, elementary school, literacy, reading fondness, teaching and learning

Received 24 August 2021; Accepted 22 November 2021; Published 24 December 2021

Citation: Aziz, R., Susanto, D., Safitri., S.I., Mazida, L.I. \& Wijaya, T. (2021). Literacy learning problems: Developing the character of reading fondness in elementary school students during the COVID-19. Premiere Educandum: Jurnal Pendidikan Dasar dan Pembelajaran, 11(2), 243 - 253. Doi.org/10.25273/ pe.v11i2.10221

\section{(cc) BY-NC-SA}

Published by Universitas PGRI Madiun. This work is licensed under the Creative Commons Attribution-NonCommercialShareAlike 4.0 International License. 


\section{INTRODUCTION}

Various problems in the learning process have emerged in the school literacy movement. During the COVID-19 pandemic, schools were required to conduct online learning, which resulted in the emergence of problems teachers face in preparing and implementing learning (Rasmitadila et al., 2020; Wahyuni, Aziz, Wargadinata, \& Efiyanti, 2021), as well as issues faced by students (Ariyanti, 2020; Schlenz, 2020). Several studies have shown that students have a low reading fondness (Barnes, 2016; Hu, 2018), even though this character is essential for students' academic development (Sukesi, 2019; Sylaj \& Sylaj, 2020). Experts have pointed out these conditions, who stated the importance of reading fondness in students' personality and educational development (Izzati, Bachri, Sahid, \& Indriani, 2019; Walker, 2015).

Studies on the character development of a reading fondness in students can be categorized into two types. First, studies that make the character reading fondness due to a learning process are conducted experimentally (Fathiara, Badarudin, \& Muslim, 2019; Purpura, 2017) and non-experimental (Leu, 2016; Saepudin, Damayani, \& Komariah, 2020). Second, the study of reading fondness due to an academic condition, either in the school environment (Syamsuri, M. Hosnan, \& Jamaludin, 2020) or in the form of teacher behaviour and characteristics (Febriandari, 2019). The two categories of research above show that reading fondness in students can be developed through an educational process. This research elaborates the second approach by describing the form of reading behaviour and studying the role of teachers in the context of learning during the COVID-19 pandemic.

Lockdown policies during the pandemic have had real consequences in the world of education (Patra, 2020). The learning process takes place in a new way using online media in response to the COVID-19 pandemic (Chattopadhyay, 2021). Online learning is generally defined as a form of learning by delivering learning content through electronic media by relying on the internet as the primary access for communication and interaction between students and teachers (Kumar, 2020). The online learning process occurs through various technologies, such as web, email, chat, texts, audio, and video conferencing connected via computer networks (Kim, 2020). In the view of Wang (2018), online learning (e-learning) concerns the concept of learning by changing the time and place of learning to allow students to learn anytime and anywhere without leaving their homes. Some experts consider that online learning has many positive impacts on the learning process, with the teacher as a facilitator (Yudiawan, Sunarso, Suharmoko, Sari, \& Ahmadi, 2021). For a while, formal education usually carried out in school buildings with a face-to-face system must then be cancelled, postponed, and transferred to online classes undertaken by students (Almonacid-Fierro, Vargas-Vitoria, De Carvalho, \& Fierro, 2021).

Teachers have an essential role in developing the character of reading fondness. The teacher's role in developing reading fondness during online learning can be grouped into three types: teacher, motivator, and controller. The role of the teacher as teacher is in charge of delivering subject matter that is carried out online (Heryadi, 2016). The role of the teacher as a motivator is tasked with motivating students always to read (Klasnić, Đuranović, \& Maras, 2020). The role of the teacher as a controller is tasked with reminding students when they do not do reading activities (Collie, 2021). These three roles show that the teacher's role is still needed in the learning process even though the teacher and students do not physically meet (Aziz, Sidik, Trimansyah, Khasanah, \& Yulia, 2020).

The character of reading fondness is defined as a pattern of one's habits to carry out reading activities from various sources that aim to obtain information widely and is one way to gain knowledge. Several studies have shown that a fondness for reading is related to the level of intelligence, creativity, and learning achievement (Knijnik, 2019; Segundo Marcos, López Ferández, Daza González, \& Phillips-Silver, 2020; Stroetinga, Leeman, \& 
Veugelers, 2021). Some of these studies show that reading fondness is a strong character to enhance the development of other characters for the student.

The purpose of this study is to complement the shortcomings of existing studies by elaborating on the role of the child's prospective teacher in learning during the Covid-19 pandemic, in particular the role of the teacher in the process of developing a child's reading habit. The form of the low level of reading fondness in children is carefully mapped. In line with that, three questions can be formulated: 1). What is the manifestation of the low level of children's interest in reading textbooks during the Covid-19 pandemic; 2 ). Why the story of reading fondness in children is low during the Covid-19 pandemic; 3). How the effect of teachers problem for low reading fondness on the student. The answers to these three questions are intended to explain how the low level of children's interest in reading has become the basis for children's development in education and personality. This article about developing the character of reading fondness in students during the Covid-19 pandemic is based on an argument that the school environment has an important and strategic role in developing the character of reading fondness in students. The school principal who acts as a director and person in charge of the continuity of the education process becomes essential in the educational process during a pandemic. Likewise, the teacher, an actor who deals directly with students in the educational process, has a strategic role in achieving learning objectives.

\section{METHODS}

\section{Research Design}

The approach in this research is qualitative research with a multi-case type that comes from primary data obtained from informants directly and secondary data in documentation from the three schools where the research is conducted. Primary data were obtained from field studies that aimed to obtain data about the character of reading fondness in students and the factors that influence this phenomenon. The student's character of reading fondness is obtained through an open questionnaire analysis given online to students. Factors affecting the level of students' reading fondness were obtained from teachers from the three schools. The selection of the three schools as research sites was based on information that the three schools have implemented the character education program. The following is a figure of a multi-case research design:

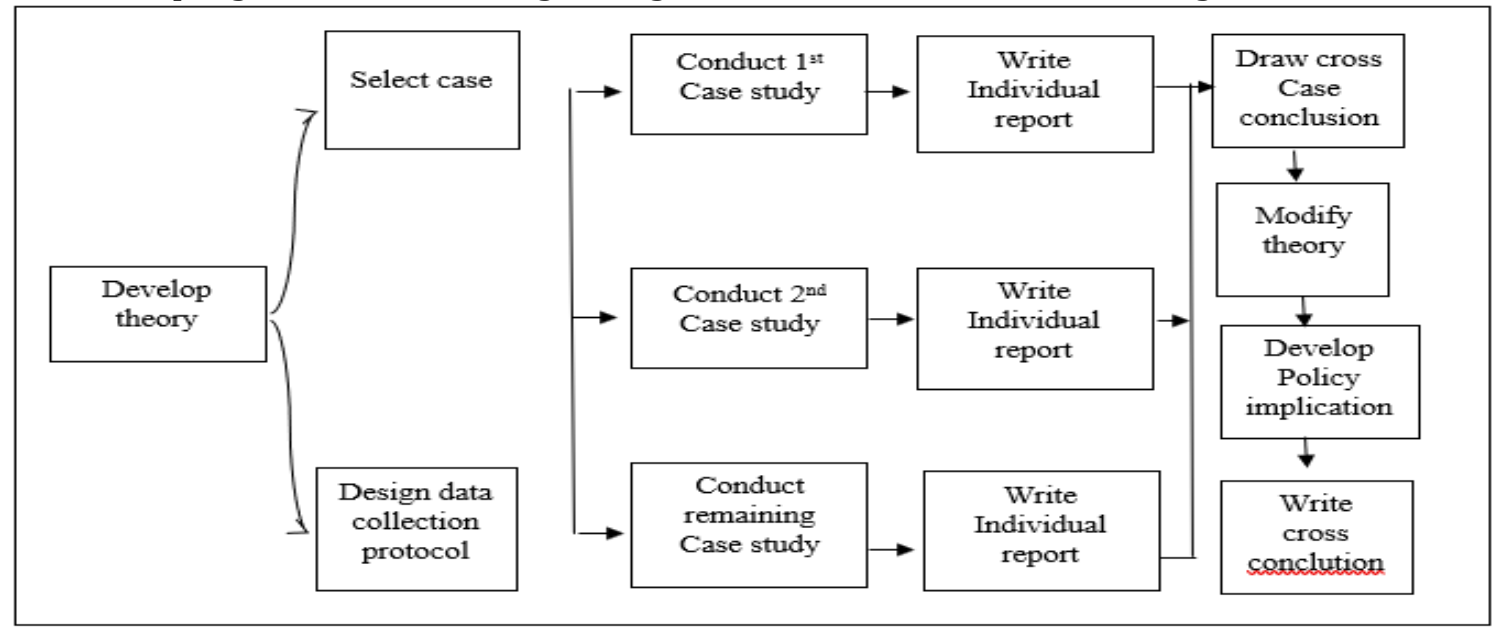

FIGURE 1. Multi-case qualitative research design

\section{The selection of cases}

The selection of cases regarding educational practices during the COVID-19 pandemic in developing a reading habit was chosen with three important considerations. First, the 
reading fondness is crucial to the design, so research on this theme still requires elaboration. Second, failure to develop character will fail in academic aspects. Third, the loss of the learning process in developing these characters necessitates an alternative learning model that can be used as a solution. The three reasons for choosing reading fondness as the issue studied in this paper indicate the hope of finding solutions to problems in education and development that are effective and innovative, especially in the implementation of reading character education for students at the elementary education level.

\section{Participant}

The data for this study were obtained from students and teachers in three schools, namely Public Elementary School 018 in Tanjung Baru Riau, Madrasah Ibtidaiyah Negeri 01 in Palangka Raya, Central Kalimantan, and Madrasah Ibtidaiyah Sabilillah in Lamongan, East Java. Complete data regarding the composition of the number of informants can be seen in table 1.

TABLE 1. Composition of the number of student and teacher informants

\begin{tabular}{|c|c|c|c|c|c|c|}
\hline & \multicolumn{3}{|c|}{ Gender } & \multicolumn{3}{|c|}{ Age } \\
\hline Student & Male & Female & Total & $11(-)$ & $12(+)$ & Total \\
\hline $\begin{array}{l}\text { 1. Elementary School } 018 \text { Tanjung Baru } \\
\text { Riau }\end{array}$ & 17 & 13 & 30 & 25 & 5 & 30 \\
\hline $\begin{array}{l}\text { 2. Islamic Elementary school } 01 \\
\text { Palangka Raya, Central Kalimantan }\end{array}$ & 25 & 40 & 65 & 26 & 39 & 65 \\
\hline $\begin{array}{l}\text { 3. Islamic Elementary school Sabilillah } \\
\text { Lamongan, East Java }\end{array}$ & 14 & 13 & 27 & 5 & 22 & 27 \\
\hline \multirow[t]{2}{*}{ Total } & 56 & 66 & 122 & 39 & 66 & 122 \\
\hline & \multicolumn{3}{|c|}{ Gender } & \multicolumn{3}{|c|}{ Age } \\
\hline Teacher & Male & Female & Total & $30(-)$ & $40(+)$ & Total \\
\hline $\begin{array}{l}\text { 1. Elementary School } 018 \text { Tanjung Baru } \\
\text { Riau }\end{array}$ & - & 2 & 2 & 1 & 1 & 2 \\
\hline $\begin{array}{l}\text { 2. Islamic Elementary school } 01 \\
\text { Palangka Raya, Central Kalimantan }\end{array}$ & 1 & 1 & 2 & - & 2 & 2 \\
\hline $\begin{array}{l}\text { 3. Islamic Elementary school Sabilillah } \\
\text { Lamongan, East Java }\end{array}$ & 2 & 1 & 3 & 2 & 1 & 3 \\
\hline Total & 3 & 4 & 7 & 2 & 5 & 7 \\
\hline
\end{tabular}

Table 1 explains that the research sites come from three elementary schools located in three provinces in Indonesia. The research subjects consisted of students and teachers from the three schools. Students aged 12 years and over are more than 11 years old. Teachers aged 40 years and over are more than 30 years old.

\section{Instrument}

Data were obtained from 122 students and seven teachers. Data was collected through open questionnaires and online interviews. The questions posed to students consisted of four questions: in a week, how many times do you read textbooks? in a week, how many times do you visit online sites to read? In a week, how many times do you read fiction? How many times do you read science and technology books? The questions posed to the teacher consisted of four topics. Namely: the teacher's view of students who like to read, the obstacles experienced in developing a student's reading fondness, the efforts made by the teacher in overcoming difficulties during the online learning process, and what learning models should be done during the pandemic. 


\section{Procedures}

The research process begins with submitting a Malang State Islamic University permit to the school used as a research site. After obtaining approval from the school, the researcher took data from students and teachers. Data from students contains the character of reading fondness. Data on teachers about the learning process during the Covid-19 pandemic. The selection of students as research subjects was based on teacher approval and students' willingness to become research subjects. Data retrieval on students is done through Google forms, while data collection on teachers is done through interviews with telephone facilities.

\section{Data analysis}

Data from both students and teachers were analyzed through the following stages: First, the data were analyzed by grouping answers based on emerging themes. Data from students were grouped into three themes, while data from teachers were grouped into two themes. Second, count the number of frequencies that appear in each theme. Third, conduct a critical analysis of the relationship between the love of reading in students and the teacher's role in the learning process. The three stages of the analysis were carried out to understand the meaning of the teacher's role during the COVID-19 pandemic in developing a love for reading in elementary education level students.

\section{RESULTS}

In this section, three research findings of reading character education are presented during the COVID-19 pandemic, namely the frequency of student activity in reading, the type of student activity in reading, and the role of the teacher in learning to love reading in students.

\section{Student activities in reading}

This data is obtained from two questions: 1 ) How often do you read textbooks in a week? The answer is given two choices, namely often and rarely. If the answer is usually, the next question is what books are read the most? Meanwhile, if the answer is rarely, the next question is, why do you rarely read textbooks? 2) In a week, how many times do you visit online sites? If the answer is often, the next question is, why do you see online sites?

Meanwhile, if the answer is rarely, the next question is, why do you rarely visit online sites? Data in the field shows that from 122 students, 47 students answered that they often read books and 63 frequently visited online sites, while those who responded rarely read books were 73 , and 39 who rarely visited online sites. The complete data is in table 2 .

TABLE 2. Student activities in reading

\begin{tabular}{|c|c|c|c|c|c|c|c|c|}
\hline Question & Answer & Explanation & $\sum$ & $\%$ & Answer & Explanation & $\sum$ & $\%$ \\
\hline \multirow{4}{*}{$\begin{array}{l}\text { How many times a } \\
\text { week do you read } \\
\text { textbooks? }\end{array}$} & \multirow{4}{*}{ often } & Religion & 13 & 11 & \multirow{4}{*}{ seldom } & Not interesting & 27 & 36 \\
\hline & & Thematic book & 20 & 16 & & Play & 25 & 33 \\
\hline & & Fictions & 14 & 11 & & Other & 23 & 31 \\
\hline & & Total & 47 & 39 & & Total & 75 & 61 \\
\hline In a week, how & \multirow{4}{*}{ often } & Read a story & 29 & 24 & \multirow{4}{*}{ seldom } & No internet & 15 & 12 \\
\hline many times do & & Read a news & 7 & 6 & & Not interesting & 44 & 36 \\
\hline you visit online & & Others & 27 & 22 & & - & 0 & 0 \\
\hline sites to read? & & Total & 63 & 52 & & Total & 59 & 48 \\
\hline
\end{tabular}


Table 2 explains that the number of students who rarely read books was more than that of students who read frequently. It shows that there is a problem in the character of reading fondness. However, when the questions were in the form of online reading, it turned out that the number of students who read frequently was more than those who rarely read. These results indicate a tendency for students to read more online than conventionally.

\section{Types of Student Reading Activities}

This data is obtained from two questions, namely: 1) in a week, how many times do you read fiction books? The answer is given two choices, namely often and rarely. If the answer is usually, the next question is, what book have you read? Meanwhile, if the answer is rarely, the next question is, why do you rarely read fiction books? 2) in a week, how many times do you read science and technology books? If the answer is often, the next question is science and technology books about what do you read? Meanwhile, if the answer is rarely, the next question is, why do you rarely read science and technology books? The data in the field showed that from 122 students, 58 students answered that they often read fiction books and 48 read science and technology books, while those who responded that they rarely read fiction books were 64 , and 74 who rarely read science and technology books. The complete data is in table 3 .

TABLE 3. Types of student reading

\begin{tabular}{|c|c|c|c|c|c|c|c|c|}
\hline Question & Answer & Explanation & $\sum$ & $\%$ & Answer & Explanation & $\sum$ & $\%$ \\
\hline \multirow{4}{*}{$\begin{array}{l}\text { How many } \\
\text { times a week } \\
\text { do you read } \\
\text { fiction? }\end{array}$} & \multirow{4}{*}{ often } & Fairytale & 12 & 21 & \multirow{4}{*}{ Seldom } & Lazy & 25 & 39 \\
\hline & & Folklore & 31 & 53 & & Don't like & 23 & 36 \\
\hline & & Prophet story & 15 & 26 & & Don't have a book & 16 & 25 \\
\hline & & Total & 58 & 100 & & Total & 64 & 100 \\
\hline \multirow{4}{*}{$\begin{array}{l}\text { How many } \\
\text { times a week do } \\
\text { you read science } \\
\text { and technology? }\end{array}$} & \multirow{4}{*}{ often } & Science & 18 & 38 & \multirow{4}{*}{ Seldom } & Not interesting & 35 & 47 \\
\hline & & Technology & 30 & 62 & & Difficult & 25 & 34 \\
\hline & & - & 0 & 0 & & Don't have a book & 14 & 19 \\
\hline & & Total & 48 & 100 & & Total & 74 & 100 \\
\hline
\end{tabular}

Table 3 explains that the number of students who rarely read books, both fiction and science, was more than those who often read. It shows that there is a problem in the character of reading fondness. From the reasons they rarely read, it turns out that the reasons for not being interested and lazy to read are the most dominant.

\section{The role of the teacher in the learning process}

Data regarding developing the character of reading fondness in students were obtained from nine teachers from three schools. The data were obtained through four questions, namely the teacher's view of students who like to read, the obstacles experienced in developing students' reading fondness, the efforts made by the teacher in overcoming difficulties during the online learning process, and what learning models should be utilized during the pandemic. The answers to the four questions were then grouped into two groups, then the answers were calculated with the number of frequencies and percentages. The complete data is in table 4.

TABLE 4. Difficulties and efforts of teachers in developing a reading fondness

\begin{tabular}{lllll}
\hline No & Topic Questions & Finding & $\sum$ & $\%$ \\
\hline 1 & The teacher's view of students & Students who have reading awareness & 5 & 71.43 \\
& liking to read & Students who have high curiosity & 2 & 28.57 \\
2 & Perceived barriers & Facility & 4 & 57.14 \\
& & Busy parents & 3 & 42.86
\end{tabular}




\section{Efforts made}

4 The ideal learning model
Reminding and motivating student

Controlling students

Free learning

Learning through habituation
57.14

42.86

57.14

42.86

Table 4 explains that teachers have a positive view of students who like to read. However, teachers have problems with online learning. Teachers also try to overcome these difficulties in a way, although the results are not satisfactory. The difficulty of teachers in carrying out online learning results in the low quality of learning outcomes for students, including the typical character of reading fondness. An explanation of the relationship between data on the character of students and teacher difficulties is in figure 2 .

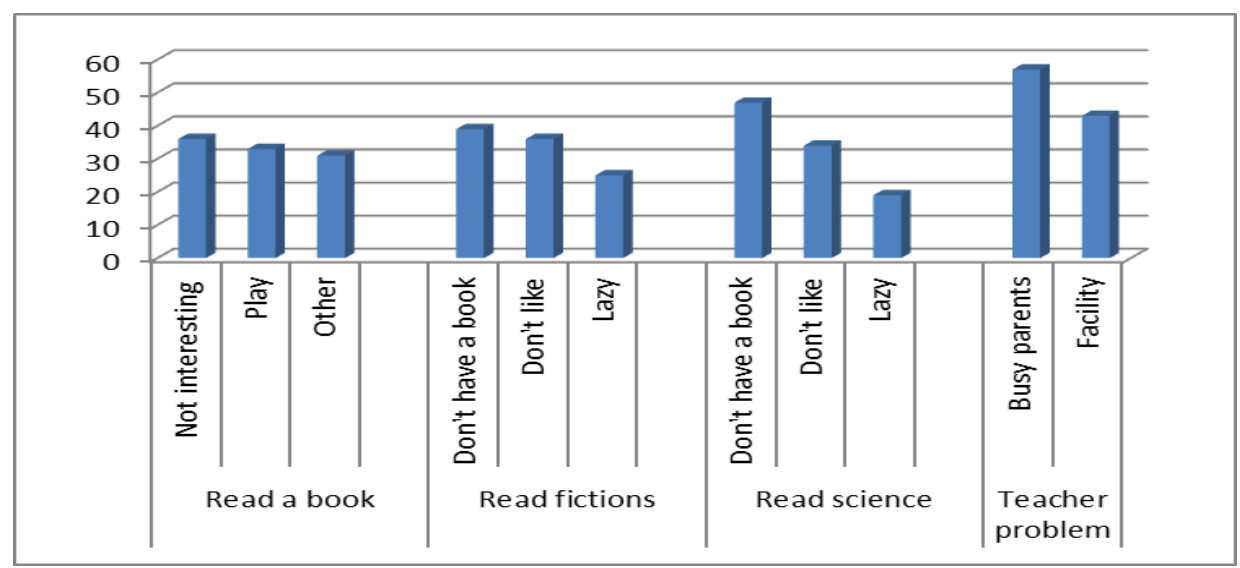

FIGURE 2. Histogram of students character and teacher difficulties

Based on the presentation of the data in the three tables and figure 2, it can be explained that there are students who have a low character in reading, both offline and online. This is characterized by disinterest in reading, and they prefer to play rather than read. Other data indicate that there are problems with facilities and infrastructure that hinder reading activities. This is characterized by students who do not have books and have difficulty using the internet network. Further data shows that teachers have problems in carrying out the online learning process. The three data indicate a relationship between teacher teaching activities and students' level of reading fondness.

\section{DISCUSSION}

This study shows that the characteristics of students' reading fondness can be grouped into two groups, namely the group that often reads and the group that rarely reads. The teacher's role can influence students' reading interest in overcoming problems that arise during the pandemic. The critical role played by the teacher is to motivate them to continue reading during the online learning process. The results of this study reflect the close academic and psychological relationship between teachers and students. In other words, teaching teachers are not only oriented to efforts to increase understanding or skills in the field of study but also must consider the psychological aspects of students. Reading fondness is an important psychological aspect to be developed as a basic model for student development in various aspects. Several studies have shown that teachers who pay attention will increase the multiple potentials of their students (Rahimi, 2015; Turner, 2019).

The analysis results show that there are students who have a low level of fondness for reading. Two factors cause the high and low character of reading fondness in students. First, factors that come from the students themselves, such as study habits, motivation, and intelligence. Second, factors outside the students include educational programs, facilities, parents, and teachers (Labudasari \& Rochmah, 2019; Wittentirelli, Herman 
Saputra, \& Putra, 2019). Among these factors, it turns out that the teacher in the learning process plays a very important and strategic role in efforts to develop student character.

The analysis of the teacher's role in learning shows two difficulties in carrying out online learning. The first difficulty relates to the limited facilities teachers own in the schools and students in the home, especially problems related to the internet network. This result aligns with several previous findings, which yielded the same finding (Intania \& Sutama, 2020; Satianingsih, Budiyono, \& Subandowo, 2020). The second difficulty relates to the teacher's ability to deliver lessons. These results indicate the importance of improving and developing teacher professionalism by the school and government.

This study implies that the teacher method delivers interesting and professional material that can motivate students to study at home. This condition will have a positive psychological impact by increasing students' interest in reading more diligently. Psychologically, when teachers pay attention to their students, they feel comfortable with these conditions, so they are more motivated to learn (Cooper, 2011; Sutarto, Sari, \& Fathurrochman, 2020). This study also shows that the teacher's efforts to deal with learning difficulties during the pandemic impact the highs and lows of student character. These results indicate that the teacher's role in developing student character is irreplaceable under any circumstances (Aperribai, Cortabarria, Aguirre, Verche, \& Borges, 2020).

There have been many studies that examine the character of reading fondness in students. For example, research that examines these characters creates a conducive school environment and movement (Davies et al., 2013; Husain \& Anggraini, 2020). The study examines the nature of reading fondness as a factor that influences other aspects (Hattarina, Pratama, \& ., 2020) and research that specifically examines the role of teachers in developing a reading habit (Sugiani, Adhijaya, \& Restami, 2020). The results of this study indicate a conclusion that the character of reading fondness can be developed in various ways. In this study, the character of reading fondness is described in detail to explain the basics behind student behaviour. In addition, the teacher's role during online learning is elaborated in-depth to understand the teacher's role in developing the reading character of elementary school students.

The study results provide practical recommendations that for Strengthening the role of teachers in efforts to develop the character of reading fondness, every teacher can do so in all subjects. In the learning process, the teacher can develop a character reading fondness by designing learning objectives that are nurturing (Liu, 2020; Schultz, 2015). The character of reading fondness is one of the students' potentials that can be developed for this purpose. However, along with the COVID-19 pandemic, the learning concept that emphasizes the nurturing effect will change its form and function. Therefore, further research needs to consider how this concept can be implemented in educational practice.

\section{CONCLUSION}

An essential finding of the study showed that the low character of students' reading fondness was caused by the difficulties of the teacher in carrying out the learning process. These findings indicate that the COVID-19 pandemic has the effect of a social transformation in educational practice. Educational practice, which has been understood as a one-way process of providing information, has turned into an interactive process involving various parties. This study suggests a solution in the form of the importance of teachers in developing students' reading fondness. Teachers not only act as teachers who deliver the subject matter to students, but they must also be able to become motivators to encourage students to continue reading. In addition, the teacher must also be able to be a controller of students who are at home. These three roles necessitate the importance of developing teacher competence in carrying out their duties professionally.

This research is limited to online data, either through questionnaires given to students or direct interviews with teachers. As an essential technique in qualitative 
research, the observation method was not used because of the pandemic conditions that made it impossible to do. Likewise, the informants' views as the basis for inferences on implementing students reading fondness character learning still do not reflect in-depth data. Based on these limitations, further research needs to be carried out by paying attention to data collection techniques and selecting more appropriate informants to understand the problems in depth.

\section{REFERENCES}

1. Almonacid-Fierro, A., Vargas-Vitoria, R., De Carvalho, R. S., \& Fierro, M. A. (2021). Impact on teaching in times of COVID-19 pandemic: A qualitative study. International Journal of Evaluation and Research in Education, 10(2), 432-440. https://doi.org/10.11591/ijere.v10i2.21129

2. Aperribai, L., Cortabarria, L., Aguirre, T., Verche, E., \& Borges, Á. (2020). Teacher's Physical Activity and Mental Health During Lockdown Due to the COVID-2019 Pandemic. Frontiers in Psychology, 11. https://doi.org/10.3389/fpsyg.2020.577886

3. Ariyanti, G. (2020). The effects of online mathematics learning in the Covid-19 pandemic period: A case study of senior High School students at Madiun City, Indonesia. Mathematics Teaching-Research Journal, 12(3), 4-11. Retrieved from https://api.elsevier.com/content/abstract/scopus_id/85104231169

4. Aziz, R., Sidik, N. A. H., Trimansyah, T., Khasanah, N., \& Yulia, N. M. (2020). Model Suasana Kelas yang Mensejahterakan Siswa Tingkat Pendidikan Dasar. Mediapsi, 6(2), 94-101. https://doi.org/10.21776/ub.mps.2020.006.02.3

5. Barnes, A. (2016). Low-skilled adult readers look like typically developing child readers: a comparison of reading skills and eye movement behavior. Reading and Writing, 29(9), 18891914. https://doi.org/10.1007/s11145-016-9657-5

6. Chattopadhyay, S. (2021). A study of the adaptation to innovative online teaching-learning pedagogy by stakeholders in Covid times. Indian Journal of Ecology, 48, 89-93. Retrieved from https://api.elsevier.com/content/abstract/scopus_id/85110759936

7. Collie, R. J. (2021). COVID-19 and Teachers' Somatic Burden, Stress, and Emotional Exhaustion: Examining the Role of Principal Leadership and Workplace Buoyancy. AERA Open, 7. https://doi.org/10.1177/2332858420986187

8. Cooper, B. (2011). Empathy in education: engagement, values and achievement. London; New York, NY: Continuum. Retrieved from http://public.eblib.com/choice/publicfullrecord.aspx?p=793286

9. Davies, D., Jindal-Snape, D., Collier, C., Digby, R., Hay, P., \& Howe, A. (2013). Creative learning environments in education-A systematic literature review. Thinking Skills and Creativity, 8, 8091. https://doi.org/10.1016/j.tsc.2012.07.004

10. Fathiara, A., Badarudin, B., \& Muslim, A. H. (2019). Meningkatkan keterampilan berpikir kritis dan gemar membaca peserta didik melalui model predict observe explain berbasis literasi. Muallimuna: Jurnal Madrasah Ibtidaiyah, 92. https://doi.org/10.31602/muallimuna.v4i2.1863

11. Febriandari, E. I. (2019). Penanaman nilai karakter gemar membaca berbasis pembiasaan dan keteladanan terhadap kemampuan berbahasa siswa sekolah dasar. Journal AL-Mudarris, 2(2). https://doi.org/10.32478/al-mudarris.v2i2.286

12. Hattarina, S., Pratama, H., \& . S. (2020). Kegiatan membaca lebih unggul daripada menonton dalam melatih keterampilan berpikir kritis anak. Jurnal IKA PGSD (Ikatan Alumni PGSD) UNARS, 8(2). https://doi.org/10.36841/pgsdunars.v8i2.839

13. Heryadi, D. (2016). Academic characters development through logical-based lecturing. Jurnal Pendidikan Dan Kebudayaan, 1(3), 317-330.

14. $\mathrm{Hu}, \mathrm{X}$. (2018). The relationship between ICT and student literacy in mathematics, reading, and science across 44 countries: A multilevel analysis. Computers and Education, 125, 1-13. https://doi.org/10.1016/j.compedu.2018.05.021

15. Husain, M. N., \& Anggraini, D. (2020). Kampanye Pemasaran Sosial Gemar Membaca Berbasis Media Sosial di Masa Pandemi Covid-19. Prosiding Nasional Covid-19.

16. Intania, E. V., \& Sutama, S. (2020). The role of character education in learning during the COVID-19 pandemic. Jurnal Penelitian Ilmu Pendidikan, 13(2). https://doi.org/10.21831/jpipfip.v13i2.32979 
17. Izzati, U. A., Bachri, B. S., Sahid, M., \& Indriani, D. E. (2019). Character education: Gender differences in moral knowing, moral feeling, and moral action in elementary schools in Indonesia. Journal for the Education of Gifted Young Scientists, $7(3)$. https://doi.org/10.17478/jegys.597765

18. Kim, J. (2020). Learning and Teaching Online During Covid-19: Experiences of Student Teachers in an Early Childhood Education Practicum. International Journal of Early Childhood, 52(2). https://doi.org/10.1007/s13158-020-00272-6

19. Klasnić, I., Đuranović, M., \& Maras, N. (2020). Peer cooperation between students and teacher support in different school subjects classes. Croatian Journal of Education, 22(Specialedition3), 21-36. https://doi.org/10.15516/cje.v22i0.3907

20. Knijnik, J. (2019). Reading and writing the game: Creative and dialogic pedagogies in sports education. Thinking Skills and Creativity, 32, 42-50. https://doi.org/10.1016/j.tsc.2019.03.005

21. Kumar, G. (2020). Outcome of online teaching-learning over traditional education during covid-19 pandemic. International Journal of Advanced Trends in Computer Science and Engineering, 9(5), 7704-7711. https://doi.org/10.30534/ijatcse/2020/113952020

22. Labudasari, E., \& Rochmah, E. (2019). Pengaruh gerakan literasi sekolah terhadap karakter mandiri siswa di SDN Kanggraksan Cirebon. Premiere Educandum : Jurnal Pendidikan Dasar Dan Pembelajaran, 9(1), 57. https://doi.org/10.25273/pe.v9i1.4254

23. Leu, D. J. (2016). Literacy and technology: Deictic consequences for literacy education in an information age. Handbook of Reading Research, Vol. 3, pp. 743-770. Retrieved from https://api.elsevier.com/content/abstract/scopus_id/85071545019

24. Liu, H. Y. (2020). Nurturing and Enhancing Creativity of Nursing Students in Taiwan: A QuasiExperimental Study. Journal of Creative Behavior, 54(4), 799-814. https://doi.org/10.1002/jocb.407

25. Patra, S. (2020). COVID-19 lockdown and school closure: Boon or bane for child mental health, results of a telephonic parent survey. Asian Journal of Psychiatry, Vol. 54. https://doi.org/10.1016/j.ajp.2020.102395

26. Purpura, D. J. (2017). Foundations of mathematics and literacy: The role of executive functioning components. Journal of Experimental Child Psychology, 153, 15-34. https://doi.org/10.1016/j.jecp.2016.08.010

27. Rahimi, M. (2015). The role of teachers' classroom discipline in their teaching effectiveness and students' language learning motivation and achievement: A path method. Iranian Journal of Language Teaching Research, 3(1), 57-82. Retrieved from https://api.elsevier.com/content/abstract/scopus_id/84958778774

28. Rasmitadila, Aliyyah, R. R., Rachmadtullah, R., Samsudin, A., Syaodih, E., Nurtanto, M., \& Tambunan, A. R. S. (2020). The perceptions of primary school teachers of online learning during the covid-19 pandemic period: A case study in Indonesia. Journal of Ethnic and Cultural Studies, 7(2). https://doi.org/10.29333/ejecs/388

29. Saepudin, E., Damayani, N. A., \& Komariah, N. (2020). Pembentukan Karakter Anak Gemar Membaca Melalui Pembacaan Buku Cerita. Baca: Jurnal Dokumentasi Dan Informasi, 41(2), 41i2.467. https://doi.org/10.14203/j.baca.v41i2.467

30. Satianingsih, R., Budiyono, S. C., \& Subandowo, M. (2020). Character Education in Multicultural Society: Case in Indonesia. International Journal of Multicultural and Multireligious Understanding, 7(4).

31. Schlenz, M. A. (2020). Students' and lecturers' perspective on the implementation of online learning in dental education due to SARS-CoV-2 (COVID-19): A cross-sectional study. BMC Medical Education, 20(1). https://doi.org/10.1186/s12909-020-02266-3

32. Schultz, J. (2015). Cliché as reification: Nurturing criticality in the undergraduate creative $\begin{array}{llll}\text { writing } & \text { New } & \text { Writing, } & \text { 79-90. }\end{array}$ https://doi.org/10.1080/14790726.2014.985687

33. Segundo Marcos, R. I., López Ferández, V., Daza González, M. T., \& Phillips-Silver, J. (2020). Promoting children's creative thinking through reading and writing in a cooperative learning classroom. Thinking Skills and Creativity, 36. https://doi.org/10.1016/j.tsc.2020.100663

34. Stroetinga, M., Leeman, Y., \& Veugelers, W. (2021). Primary School Teachers' Practices of Collaborating With Parents on Upbringing. School Community Journal, 31(1), 259-282.

35. Sugiani, K. A., Adhijaya, A. A. N., \& Restami, M. P. (2020). Upaya meningkatkan minat baca anak desa yayasan project jyoti bali (YPJB) melalui storytelling di masa pandemi. Jurnal Abdimas Ilmiah Citra Bakti, 1(2). https://doi.org/10.38048/jailcb.v1i2.117

36. Sukesi, E. (2019). Reading habits, grammatical knowledge, creative thinking, and attainment in 
academic writing: Evidence from bengkulu university, Indonesia. Journal of Social Studies Education Research, 10(3), 176-192. Retrieved from https://api.elsevier.com/content/abstract/scopus_id/85073461559

37. Sutarto, S., Sari, D. P., \& Fathurrochman, I. (2020). Teacher strategies in online learning to increase students' interest in learning during COVID-19 pandemic. Jurnal Konseling Dan Pendidikan, 8(3). https://doi.org/10.29210/147800

38. Syamsuri, C. K., M. Hosnan, \& Jamaludin, U. (2020). Penanaman Karakter Gemar Membaca Melalui Program LIterasi Sekolah Rakica di SD Negeri Taman Ciruas Permai. Jurnal Pendidikan Dasar Nusantara, 6(1). https://doi.org/10.29407/jpdn.v6i1.14424

39. Sylaj, V., \& Sylaj, A. K. (2020). Parents and teachers' attitudes toward written communication and its impact in the collaboration between them: Problem of social study education. Journal of Social Studies Education Research, 11(1), 104-126. Retrieved from https://files.eric.ed.gov/fulltext/EJ1251912.pdf

40. Turner, K. (2019). Teacher wellbeing: Its effects on teaching practice and student learning. Issues in Educational Research, 29(3), 938-960. Retrieved from https://api.elsevier.com/content/abstract/scopus_id/85071388276

41. Wahyuni, E. N., Aziz, R., Wargadinata, W., \& Efiyanti, A. Y. (2021). Investigation of Primary School Teacher Readiness in Online Learning during the Covid-19 Pandemic. Madrasah: Jurnal Pendidikan Dan Pembelajaran Dasar, 13(2), 97-113. https://doi.org/10.18860/mad.v13i2.11343

42. Walker, D. (2015). Towards a new era of character education in theory and in practice. Educational Review, 67(1), 79-96. https://doi.org/10.1080/00131911.2013.827631

43. Wang, Q. (2018). Learning Attentions: Residual Attentional Siamese Network for High Performance Online Visual Tracking. Proceedings of the IEEE Computer Society Conference on Computer Vision and Pattern Recognition, pp. 4854-4863. https://doi.org/10.1109/CVPR.2018.00510

44. Wittentirelli, W., Herman Saputra, A., \& Putra, A. E. (2019). Analisis Karakter Gemar Membaca Siswa SMP Negeri 30 Muaro Jambi. Briliant: Jurnal Riset Dan Konseptual, 4(2). https://doi.org/10.28926/briliant.v4i2.305

45. Yudiawan, A., Sunarso, B., Suharmoko, Sari, F., \& Ahmadi. (2021). Successful online learning factors in covid-19 era: Study of islamic higher education in west papua, indonesia. International Journal of Evaluation and Research in Education, 10(1), 193-201. https://doi.org/10.11591/ijere.v10i1.21036

\section{PROFILE}

Dr. Rahmat Aziz, M.Si. The author is a lecturer at the Faculty of Psychology, State Islamic University of Malang. His area of expertise is educational psychology. The focus of the study that interests him is the study of learning models, character education, creativity, student wellbeing, and mental health.

Djoko Susanto, M.Ed., Ph.D. The author is a teaching staff in the department of English education. His area of expertise is writing and critical thinking. The focus of the study that interests him is the model of language learning, writing skills, critical thinking, and character education.

Sabilla Irwina Safitri, S.Pd. The author is an alumnus of the Madrasah Ibtidaiyah teacher education, Lamongan Islamic University, East Java. She is currently registered as a student of the master's degree program for the madrasah ibtidaiyah teacher education, State Islamic University of Malang. She is interested in the field of study on character education, teaching and learning models. Lina Izza Mazida, S.Pd. The author is an alumnus of Madrasah Ibtidaiyah teacher education, Palangkaraya State Islamic Institute, Central Kalimantan. She is currently registered as a student of the master's degree program for the madrasah ibtidaiyah teacher education, State Islamic University of Malang. She is interested in the field of study on character education, teaching and learning models.

Thomas Wijaya, S.Pd. The author is an alumnus of the ibtidaiyah madrasah teacher education, Auliaurrosyidin Islamic College, Tembilahan Riau. He is currently registered as a student of the master's degree program for the madrasah ibtidaiyah teacher education, State Islamic University of Malang. He is interested in the field of study on character education and learning models. 